Journal of Healthcare Technology and Medicine Vol. 6 No. 2 Oktober 2020

Universitas Ubudiyah Indonesia

e-ISSN : 2615-109X

\title{
Perspektif Agama Islam Dan Kesehatan Tentang Penggunaan Alat Kontrasepsi (Akjp) Implant Di BPM Keluarga Sehat Kecamatan Darul Hasanah Kabupaten Aceh Tenggara Provinsi Aceh Tahun 2019
}

\author{
Islamic and Health Perspectives on the Use of Implant Contraceptives at BPM \\ Healthy Families, Darul Hasanah District Southeast Aceh District Aceh Province \\ in 2019
}

\author{
Karmila $^{* 1}$, Fatma Sylvana Dewi Harahap ${ }^{2}$, Rapida Saragih ${ }^{3}$ \\ 1,2,3 Institut Kesehatan Helvetia, Jl. Kapten Sumarsono No. 107, Medan 20124 \\ "Koresponding Penulis: ${ }^{1}$ kkarmila025@ gmail.com, ${ }^{2}$ fatmaharahap80@ gmail.com, ${ }^{3}$ pida81saragih@ @mail.com
}

\begin{abstract}
ABSTRAK
Menurut WHO (World Health Organization) penggunaan kontrasepsi telah meningkat di banyak bagian Dunia, terutama di Asia dan Amerika Latin dan terendah di Afrika. Secara global, penggunaan kontrasepsi modern telah meningkat dari 54\% pada tahun 1990 menjadi 63,4\% pada tahun 2017. Tujuan penelitian ini adalah untuk menganalisis persfektip Agama Islam dan Kesehatan Tentang Penggunaan Alat Kontrasepsi Jangka Panjang Implant di BPM Keluarga Sehat Kabupaten Aceh Tenggara. Jenis penelitian ini menggunakan Mix Methods.Populasi dalam penelitian ini berjumlah wus yang berkunjung ke Klinik dan sampel sebanyak 42 responden, sedangkan untuk informan kualitatif 2 wanita usia subur yang tidak memakai alat kontrasepsi implant, 2 suami, 1 bidan dan 1 kepala Desa dan 1 Ustad Kampung. Berdasarkan hasil uji chi-square diperoleh pada variabel umur $\mathrm{p}=0,648$ pendidikan $\mathrm{p}=0,012$, pengetahuan $\mathrm{p}=0,000$, Jarak pelayanan kesehatan $\mathrm{p}=1,000$, paritas $\mathrm{p}=0,571$, dukungan suami $\mathrm{p}=0,005$, sikap $=0,012$, dengan faktor yang paling berpengaruh adalah jarak tempat kesehatan dan dukungan suami. Secara kualitatif berdasarkan wawancara mendalam terhadap informan didapatkan bahwa yang menyebabkan wanita usia subur tidak ingin memakai alat KB implant adalah kurangnya dukungan yang diberikan oleh suami, pengetauan. Kesimpulan dalam penelitian ini adalah ada pengaruh umur, pendidikan, pengetahuan, sikap dan dukungan suami dengan persfektip Agama Islam dan kesehatan tentang penggunaan alat kontrasepsi implant di BPM Keluarga sehat Kecamatan Darul Hasanah Kabupaten Aceh Tenggara Tahun 2019.
\end{abstract}

Kata Kunci : Persfektip Islam, Kesehatan, Penggunaan Alat Kontrasepsi Implant.

\begin{abstract}
According to WHO (World Health Organization) the use of contraception has increased in many parts of the world, especially in Asia and Latin America and lowest in Africa. Globally, the use of modern contraceptives has increased from 54\% in 1990 to $63.4 \%$ in 2017. The purpose of this study is to analyze the Islamic and Health perspective on the use of long-term implant contraceptives at BPM Keluarga Sehat, Aceh Tenggara District. This type of research used Mix Methods. The population in this study amounted to wus who visited the clinic and a sample of 42 respondents, while for qualitative informants 2 women of reproductive age who did not use implant contraceptives, 2 husbands, 1 midwife and 1 village head and 1 Ustad Village. Based on the results of the chi-square test obtained on the variable age $p=0.648$, education $p=0.012$, knowledge $p=0.000$, distance to health services $p=1,000$, parity $p=$
\end{abstract}


Journal of Healthcare Technology and Medicine Vol. 6 No. 2 Oktober 2020

Universitas Ubudiyah Indonesia

e-ISSN : 2615-109X

0.571, husband's support $p=0.005$, attitude $=0.012$, with the most influential factors is the distance between the husband's health and support. Qualitatively, based on in-depth interviews with informants, it was found that what causes women of childbearing age not to want to use implant contraceptives is the lack of support provided by their husbands, knowledge. The conclusion in this study is that there is an effect of age, education, knowledge, attitudes and support of husbands with Islamic and health perspectives regarding the use of implant contraceptives in BPM Healthy families, Darul Hasanah District, Southeast Aceh Regency in 2019.

Keywords : Islamic Perspectives, Health, Use of Implant Contraceptives.

\section{PENDAHULUAN}

Menurut WHO (World Health Organization) penggunaan kontrasepsi telah meningkat di banyak bagian Dunia, terutama di Asia dan Amerika Latin dan terendah di Sub-Sahara Afrika. Secara global, penggunaan kontrasepsi modern telah meningkat dari 54\% pada tahun 1990 menjadi 63,4\% pada tahun 2017. Di Afrika dari 23,6\% menjadi 27,6\%, di Asia telah meningkat dari 60,9\% menjadi 61,6\% sedangkan Amerika Latin dan Karibia meningkat sedikit dari 66,7\% menjadi 67,0\%. Diperkirakan 225 juta perempuan di Negara-Negara berkembang ingin menunda atau menghentikan kesuburan namun tidak menggunakan kontrasepsi apapun. Hal ini dipengaruhi oleh terbatasnya pilihan kontrasepsi yang ada, ketakutan akan pengalaman efek samping, Agama, rendahnya kualitas layanan, serta hambatan berbasis gender (Hartono, 2016).

Menurut World Population Data Sheet 2013, Indonesia merupakan Negara ke-5 di Dunia dengan estimasi jumlah penduduk terbanyak, yaitu 249 juta. Di antara Negara ASEAN, Indonesia dengan luas wilayah terbesar tetap menjadi Negara dengan penduduk terbanyak ke9 dari Negara anggota lain. Salah satu program untuk mengontrol laju pertumbuhan penduduk di Indonesia melalui program keluarga berencana dengan penggunaan alat kontrasepsi jangka panjang implant (Kemenkes RI, 2018).

Di Provinsi Aceh, prevalensi pemakaian alat kontrasepsi implant masih rendah berdasarkan laporan Rencana Pembangunan Jangka Menengah Nasional (RPJMN) tahun 2018 untuk Provinsi Aceh tercatat cakupannya sebanyak 51,6\% kebutuhan KB implant yang tidak terpenuhi (unmet need). Implant Salah satu alat kontrasepsi permanen yang bersifat sementara dan memiliki efektifitas yang tinggi tetapi masih sedikit wanita usia subur yang memakainya karena banyak faktor yang mempengaruhi (Dinkes Aceh, 2018).

Berdasarakan profil data Dinas Kesehatan Aceh Tenggara dari Dinas pemberdayaan perempuan, perlindungan anak, pengendalian penduduk dan keluarga berencana Aceh 
Journal of Healthcare Technology and Medicine Vol. 6 No. 2 Oktober 2020

Universitas Ubudiyah Indonesia

e-ISSN : 2615-109X

Tenggara tahun 2018 bahwa jumlah wanita usia subur (WUS) sebanyak 22.200 orang dan KB tidak aktif sebanyak 2.858 orang sedangkan peserta KB aktif sebanyak 19.341orang, menggunakan kontrasepsi suntik sebanyak 9.410 (48,7\%), pill sebanyak 6.760(33,4\%), kondom sebanyak 1.340 (6,5\%), IUD sebanyak 950 (4,9\%), MOW sebanyak 341 (3,3\%) dan MOP sebanyak $130(1,1 \%)$ dan implant sebanyak 410 (2,1\%) (Profil Kesehatan Kabupaten Aceh Tenggara, 2018).

Agama memainkan peran dalam penggunaan keluarga berencana (KB) dan menentukan metode kontrasepsi yang digunakan. Agama Islam pada hakikatnya adalah Agama pembangunan yang mengatur tata tertib dalam kehidupan manusia dalam hubungannya dengan Allah SWT dan sesama manusia. Keluarga berencana termasuk masalah yang kontroversional dalam Islam. Ada dua kelompok yang pro dan ada yang kontra terhadap pelaksanaan KB yaitu pertama Tahdid al-nasl (pembatasan kelahiran) merupakan program KB yang dimaksudkan untuk membatasi kelahiran dan hukumnya haram. Islam tidak mengenal pembatasan kelahiran. Bahkan banyak hadis yang mendorong umat Islam untuk memperbanyak anak. Kedua Tanzim al-nasl (pengaturan kelahiran) merupakan program KB yang dimaksudkan untuk mencegah kelahiran dengan berbagai cara dan sarana, maka hukumnya mubah, bagaimana pun motifnya (Aziz Alimul, 2016).

Berdasarkan data yang diperoleh dari Bidan Praktek Mandiri (BPM) Keluarga Sehat tahun 2018 bahwa jumlah secara keseluruhan Wanita Usia Subur (WUS) sebanyak 1.240 orang, KB tidak aktif sebanyak 418 orang dan KB aktif sebanyak 822 orang. Di antara wanita usia subur yang KB aktif menggunakan alat kontrasepsi pill sebanyak 261 (31,7\%), suntikan sebanyak 372 (45,2\%), kondom sebanyak 63 (7,7\%), MOW sebanyak 9 (1,1\%), MOP sebanyak 7 (1\%), IUD sebanyak $84(10,2 \%)$ dan implant sebanyak $26(3,1 \%)$.

Di Aceh termasuk mayoritas penduduk beragama Islam dan menegakkan syariat Islam, banyak kalangan masyarakat yang beragama Islam beranggapan bahwa menggunakan KB implant tidak di larang dalam Agama karena memasukkan sesuatu/benda kedalam tubuh. Wanita usia subur tidak berminat memakai alat kontrasepsi implant karena di anggap bertentangan dengan hukum Islam. Hal tersebut dapat kita lihat dengan rendahnya pemakaian alat kontrasepsi implant $(2,1 \%)$ yang di galakkan oleh Badan Koordinasi Keluarga Berencana Nasional (BKKBN) di Aceh Tenggara (Yakub, 2015).

Survey awal yang dilakukan oleh peneliti pada 10 orang wanita usia subur, di dapatkan bahwa 8 orang diantaranya dewasa muda 6 orang dan dewasa tua 2 orang, berpendidikan rendah 5 orang dan menengah 3 orang, paritas multipara 7 orang dan grandemultipara 1 orang, 
Journal of Healthcare Technology and Medicine Vol. 6 No. 2 Oktober 2020

Universitas Ubudiyah Indonesia

e-ISSN : 2615-109X

jarak pelayanan kesehatan dari rumah dekat 6 orang dan jarak jauh 2 orang, Adanya anggapan bahwa alat kontrasepsi implant tidak boleh digunakan karena bertentangan dengan Agama Islam, tidak adanya dukungan dari suami dalam penggunaan alat kontrasepsi implant sehingga wanita usia subur yang mempunyai keinginan menggunakan kontrasepsi implant memilih metode kontrasepsi selain implant dalam menjarangkan kehamilan dan wanita usai subur mengatakan bahwa tidak ingin menggunakan alat kontrasepsi implant karena implant dapat berjalan keseluruh tubuh.

Sedangkan 2 dari 10 wanita usia subur diantaranya dewasa muda, berpendidikan menengah 1 orang dan pendidikan tinggi 1 orang, paritas multipara, I orang mengatakan jarak rumah ke fasilitas pelayanan kesehatan dekat dan 1 orang mengatakan jarak jauh, mereka mengatakan bahwa menggunakan alat kontrasepsi implant karena mengandung bahan yang tidak di haramkan penggunaannya sehingga penggunaanya di perbolehkan dalam Agama Islam, mereka juga mendapat dukungan dari suami dalam pemakaian kontrasepsi implant dan mereka tidak takut dalam menggunakan kontrasepsi implant karena dalam pemakaian alat kontrasepsi implant tidak membutuhkan pembedahan yang lebar dan pemasangannya tidak membutuhkan waktu lama.

\section{METODE PENELITIAN}

Penelitian ini menggunakan Mix Methods, menurut Creswell penelitian campuran merupakan pendekatan penelitian yang mengkombinasikan antara penelitian kualitatif dengan penelitian kuantitatif. Penelitian akan dilakukan di BPM Keluarga Sehat Kecamatan Darul Hasanah Kabupaten Aceh Tenggara Provinsi Aceh. Penelitian dijadwalkan dilaksanakan bulan September sampai dengan bulan Oktober tahun 2019.

Adapun populasi dalam penelitian ini adalah keseluruhan jumlah informan yang berkunjung ke BPM Kleuarga sehat dari bulan September sampai oktober. Sampel penelitian ini bagian dari jumlah dan karakteristik yang dimiliki oleh populasi tersebut. Teknik Pengambilan sampel dengan cara Accidential Sampling yaitu sampel yang ditentukan secara kebetulan yang sesuai dengan kriteria yang telah ditentukan oleh peneliti sebanyak 42 orang. Sedangkan informan untuk pendekatan kualitatif wanita usia subur yang tidak mau menggunakan alat kontrasepsi jangka panjang (AKJP) implant berjumlah 2 orang, Suami 2 orang, Bidan Desa 1 orang, (penggulu) kepala Desa 1 orang, Ustad (imam masjid) 1 orang dan Petugas BKKBN 1 orang. Data hasil survey dianalisis dengan menggunakan uji Chi-Square dan diperkuat dengan penelitian kualitatif guna untuk memperdalam hasil dari penelitan kuantitatif. 
Journal of Healthcare Technology and Medicine Vol. 6 No. 2 Oktober 2020

Universitas Ubudiyah Indonesia

e-ISSN : 2615-109X

HASIL DAN PEMBAHASAN

Tabel 1

Distribusi Frekuensi Persfektif Agama Islam dan Kesehatan Memengaruhi

Pemakaian Alat Kontrasepsi Implant di Klinik BPM Keluarga Sehat

Kecamatan Darul Hasanah Kabupaten Aceh Tenggara

Provinsi Aceh Tahun 2019

\begin{tabular}{|c|c|c|}
\hline Variabel & $\mathbf{F}$ & Persentase \\
\hline \multicolumn{3}{|l|}{ Umur } \\
\hline Dewasa Muda & 25 & 59,5 \\
\hline Dewasa Tua & 17 & 40,5 \\
\hline \multicolumn{3}{|l|}{ Pendidikan } \\
\hline Rendah & 21 & 50,0 \\
\hline Menengah & 13 & 31,0 \\
\hline Tinggi & 8 & 19,0 \\
\hline \multicolumn{3}{|l|}{ Paritas } \\
\hline Primipara & 3 & 7,1 \\
\hline Multipara & 33 & 78,6 \\
\hline Grandemultipara & 6 & 14,3 \\
\hline \multicolumn{3}{|l|}{ Jarak Pelayanan } \\
\hline Dekat & 27 & 64,3 \\
\hline Jauh & 15 & 35,7 \\
\hline \multicolumn{3}{|l|}{ Pengetahuan } \\
\hline Kurang & 31 & 73,9 \\
\hline Cukup & 8 & 19,0 \\
\hline Baik & 3 & 7,1 \\
\hline \multicolumn{3}{|l|}{ Dukungan Suami } \\
\hline Tidak mendukung & 37 & 88,1 \\
\hline Mendukung & 5 & 11,9 \\
\hline \multicolumn{3}{|l|}{ Sikap } \\
\hline Negatif & 36 & 85,7 \\
\hline Positif & 6 & 14,3 \\
\hline
\end{tabular}

Sumber : Data Primer, 2019

Berdasarkan tabel di atas dapat dilihat bahwa dari 42 wanita usia subur pemakaian alat kontrasepsi implant mayoritas umur ibu 21-35 tahun sebanyak 25 orang (59,5\%). Pemakaian alat kontrasepsi implant berdasarkan pendidikan ibu mayoritas pendidikan rendah sebanyak 21 orang $(50,0 \%)$. Pemakaian alat kontrasepsi implant berdasarkan paritas mayoritas multipara sebanyak 33 orang $(78,6 \%)$. Pemakaian alat kontrasepsi implant berdasarkan jarak pelayanan mayoritas jarak dekat sebanyak 27 orang (64,3\%). Pemakaian alat kontrasepsi implant berdasarkan pengetahuan ibu mayoritas kurang sebanyak 31 orang $(73,9 \%)$. Pemakaian alat kontrasepsi implant berdasarkandukungan suami mayoritas suami tidak mendukung sebanyak 
37 orang $(88,1 \%)$. Pemakaian alat kontrasepsi implant berdasarkan sikap wanita usia subur mayoritas negatif sebanyak 36 orang $(85,7 \%)$.

Tabel 2

Tabulasi Silang Persfektif Agama Islam dan Kesehatan Tentang Pemakaian Alat Kontrasepsi Implant di Klinik BPM Keluarga Sehat Kecamatan Darul Hasanah Kabupaten Aceh Tenggara Provinsi Aceh Tahun 2019

\begin{tabular}{|c|c|c|c|c|c|c|c|}
\hline \multirow{3}{*}{ Variabel } & \multicolumn{4}{|c|}{ Penggunaan Implant } & \multirow{2}{*}{\multicolumn{2}{|c|}{ Jumlah }} & \multirow{3}{*}{$P$ value } \\
\hline & \multicolumn{2}{|c|}{$\begin{array}{c}\text { Tidak } \\
\text { Menggunakan }\end{array}$} & \multicolumn{2}{|c|}{ Menggunakan } & & & \\
\hline & $\mathbf{F}$ & $\%$ & $\mathbf{F}$ & $\%$ & $\mathbf{F}$ & $\%$ & \\
\hline \multicolumn{8}{|l|}{ Umur } \\
\hline Dewasa tua & 17 & 42,5 & 0 & 0 & 17 & 42,5 & 0,648 \\
\hline Dewasa muda & 23 & 57,5 & 2 & 4,8 & 25 & 757,5 & \\
\hline Total & 42 & 95,2 & 2 & 4,8 & 42 & 100 & \\
\hline \multicolumn{8}{|l|}{ Pendidikan } \\
\hline Rendah & 21 & 50,0 & 0 & 0 & 21 & 50,0 & 0,012 \\
\hline Menengah & 13 & 31,0 & 0 & 0 & 13 & 31,0 & \\
\hline Tinggi & 6 & 14,2 & 2 & 4,8 & 8 & 19,0 & \\
\hline Total & 40 & 95,2 & 2 & 4,8 & 42 & 100 & \\
\hline \multicolumn{8}{|l|}{ Paritas } \\
\hline Primipara & 3 & 7,3 & 0 & 0 & 3 & 537,3 & 0,571 \\
\hline Multipara & 31 & 31,4 & 2 & 1,6 & 33 & 78,6 & \\
\hline Grandemultipara & 6 & 15,0 & 0 & 0 & 6 & 15,0 & \\
\hline Total & 40 & 95,2 & 2 & 4,8 & 42 & 100,0 & \\
\hline \multicolumn{8}{|l|}{ Jarak Pelkes } \\
\hline Dekat & 26 & 62,0 & 1 & 2,4 & 27 & 64,3 & 1,000 \\
\hline Jauh & 14 & 33,2 & 1 & 2,4 & 15 & 53,7 & \\
\hline Total & 40 & 95,2 & 2 & 4,8 & 42 & 100,0 & \\
\hline \multicolumn{8}{|l|}{ Pengetahuan } \\
\hline Kurang & 31 & 73,8 & 0 & 0 & 31 & 73,8 & \\
\hline Cukup & 8 & 19,0 & 0 & 0 & 8 & 19,0 & 0,000 \\
\hline Baik & 2 & 4,8 & 1 & 2,4 & 3 & 7,1 & \\
\hline $\begin{array}{c}\text { Total } \\
\end{array}$ & 41 & 97,6 & 1 & 2,4 & 42 & 100,0 & \\
\hline \multicolumn{8}{|l|}{ Dukungan Suami } \\
\hline Mendukung & 3 & 7,1 & 2 & 4,8 & 5 & 11,9 & 0,005 \\
\hline Tidak Mendukung & 37 & 88,1 & 0 & 0 & 37 & 88,1 & \\
\hline Total & 40 & 95,2 & 2 & 48,0 & 42 & 100,0 & \\
\hline \multicolumn{8}{|l|}{ Sikap } \\
\hline Negatif & 36 & 85,7 & 0 & 0 & 36 & 85,7 & 0,012 \\
\hline Positif & 4 & 9,5 & 2 & 4,8 & 6 & 14,3 & \\
\hline Total & 40 & 95,2 & 2 & 4,8 & 42 & 100,0 & \\
\hline
\end{tabular}

Sumber : Data Primer, 2019

Berdasarkan Tabel 2 dapat dilihat bahwa dari 42 responden (100) mayoritas Dewasa tua tidak menggunakan alat kontrasepsi implant sebanyak 17 orang (42,5\%) Sedangkan 
mayoritas dewasa muda tidak menggunakan KB implant sebanyak 23 orang (57,5\%). Hasil uji statistik menggunakan uji chi-square menunjukkan bahwa nilai $p$-value sebesar 0,0648>0,05 yang berarti tidak ada hubungan antara umur dengan perspektif Agama Islam dan kesehatan tentang penggunaan alat kontrasepsi implant.

Pada variabel pendidikan mayoritas pendidikan rendah tidak menggunakan sebanyak 21 orang $(50,0 \%)$ sedangkan, mayoritas pendidikan menengah tidak menggunakan sebanyak 13 orang $(31,0 \%)$ sedangkan mayoritas Pendidikan tinggi tidak menggunakan sebanyak 6 orang $(14,2 \%)$. Hasil uji statistik menggunakan uji chi-square menunjukkan bahwa nilai $p$ value sebesar 0,012 <0,05 yang ada hubungan antara pendidikan dengan persfektif Agama Islam dan kesehatan tentang penggunaan alat kontrasepsi implant.

Pada variabel mayoritas paritas primipara tidak menggunakan kontrasepsi implant sebanyak 3 orang (7,3\%), mayoritas Paritas multipara tidak menggunakan sebanyak 31 orang $(31,4 \%)$ sedangkan mayoritas paritas grandemultipara tidak menggunakan Mayoritas sebanyak 6 orang $(15,0 \%)$ sedangkan. Hasil uji statistik menggunakan uji chi-square menunjukkan bahwa nilai $p$-value sebesar 0,571 > 0,05 yang berarti tidak ada hubungan antara pendidikan dengan perspektif Agama Islam dan kesehatan tentang penggunaan alat kontrasepsi implant.

Pada variabel Mayoritas jarak dekat tidak menggunakan alat kontrasepsi implant sebanyak 26 orang $(62,0 \%)$ sedangkan mayoritas jarak jauh tidak menggunakan KB implant sebanyak 14 orang $(33,2 \%)$. Hasil uji statistik menggunkan uji chi-square menunjukkan bahwa nilai $p$-value sebesar 1,000 >0,05 yang berarti tidak ada hubungan jarak pelayanan dengan perspektif Agama Islam dan kesehatan tentang penggunaan alat kontrasepsi implant.

Pada variabel mayoritas pengetahuan kurang tidak menggunakan sebanyak 31 orang $(73,8 \%)$ sedangkan mayoritas Pengetahuan cukup sebanyak 8 orang (19,0\%) sedangkan mayoritas Pengetahuan baik tidak menggunakan sebanyak 3 orang $(7,1 \%)$. Hasil uji statistik menggunakan uji chi-square menunjukkan bahwa nilai $p$-value sebesar $0,000<0,05$ yang berarti ada hubungan antara pengetahuan dengan persfektif Agama Islam dan kesehatan tentang penggunaan alat kontrasepsi implant.

Pada wanita usia subur mendapatkaan mayoritas mendukung tidak menggunakan alat kontrasepsi implant sebanyak 3 orang $(7,1 \%)$ sedangkan mayoritas suami tidak mendukung tidak menggunakan implant sebanyak 37 orang $(88,1 \%)$. Hasil uji statistik menggunkan uji chisquare menunjukkan bahwa nilai $p$-value sebesar $0,005<0,05$ yang berarti ada hubungan antara dukungan suami dengan perspektif Agama Islam dan kesehatan tentang penggunaan alat kontrasepsi implant. 
Pada variabel sikap mayoritas negatif sebanyak 36 orang $(85,7 \%)$ sedangkan mayoritasSementara sikap wanita usia subur tidak menggunakan alat kontrasepsi implant sebanyak 4 orang $(9,5 \%)$. Hasil uji statistik menggunakan uji chi-square menunjukkan bahwa nilai $p$-value sebesar 0,012 <0,05 yang berarti ada hubungan antara sikap wanita usia subur dengan perspektif Islam dan kesehatan tentang penggunaan alat kontrasepsi jangka panjang implant.

\section{Hubungan Umur Dengan Perspektif Islam dan Kesehatan Tentang Penggunaan Alat Kontrasepsi Implant di Klinik BPM Keluarga Sehat Kecamatan Darul Hasanah Kabupaten Aceh Tenggara}

Berdasarkan Tabel 2 dapat dilihat bahwa dari 42 responden (100) mayoritas Dewasa tua tidak menggunakan alat kontrasepsi implant sebanyak 17 orang (42,5\%) Sedangkan mayoritas dewasa muda tidak menggunakan KB implant sebanyak 23 orang (57,5\%). Hasil uji statistik menggunakan uji chi-square menunjukkan bahwa nilai $p$-value sebesar 0,0648>0,05 yang berarti tidak ada hubungan antara umur dengan perspektif Agama Islam dan kesehatan tentang penggunaan alat kontrasepsi implant.

Hasil ini tidak sejalan dengan Penelitian Syafneli dengan judul analisis Faktor-Faktor yang berhubungan dengan rendahnya minat ibu dalam menggunakan KB implant di Desa Talikumain Wilayah Kerja Puskesmas Tambasui Kabupaten Rokan Hulu diperoleh hasil penelitian bahwa ada hubungan umur (pvalue $=0,007<\alpha=0,05$ ), pengetahuan (pvalue = $0,002<\alpha=0,05$ ), pendidikan (pvalue $=0,004<\alpha=0,05$ ), parietas (pvalue $=0,003<\alpha=0,05$ ) Dengan demikian ada hubungan yang signifikan antara umur, pengetahuan, pendidikan dan parietas dengan pemakaian KB implant Desa Talikumain Wilayah Kerja Puskesmas Tambasui Kabupaten Rokan Hulu (Syafneli, 2014).

Secara kualitatif diketahui bahwa informan 1 memiliki umur 23 tahun dan informan 1 memiliki umur 31 tahun. Dari kedua informan tersebut, dapat dilihat bahwa informan 1 berada pada usia dewasa muda sedangkan informan 2 berada pada usia dewasa tua.

Menurut temuan peneliti ibu hamil dengan kategori umur tidak beresiko (20-35 tahun) lebih banyak dalam melakukan pemeriksaan ANC. Ibu yang tergolong usia 20-35 tahun memiliki kesiapan yang baik untuk hamil, dimana selama proses kehamilan diperlukan kematangan fisik, emosi maupun psikologi dari ibu hamil itu sendiri. Proses kehamilan perlu didukung oleh kesabaran, pemahaman dan juga keterampilan ibu dalam menjaga kehamilannya tetap berlangsung baik dan normal demi keselamatan dirinya dan juga janin yang dikandung. Berbeda dengan ibu yang hamil di usia <20 tahun, yang masih belum begitu matang secara fisik, emosi, maupun psikologi. Begitupun ibu hamil dengan usia >35 tahun yang sebenarnya 
sudah memiliki kematangan emosi maupun psikologi yang baik, namun karena pengalamannya yang dirasa cukup sering kali membuat ibu hamil tersebut lalai dalam melakukan pemeriksaan.

Hubungan Pendidikan Dengan Perspektif Islam dan Kesehatan Tentang Penggunaan Alat Kontrasepsi Implant di Klinik BPM Keluarga Sehat Kecamatan Darul Hasanah Kabupaten Aceh Tenggara

Berdasarkan Tabel 2 dapat dilihat bahwa dari dari 42 responden didapatkan penelitian didapatkan pendidikan rendah tidak menggunakan sebanyak 21 orang $(50,0 \%)$ sedangkan minoritas pendidikan rendah menggunakan alat kontrasepsi implant sebanyak 0 orang $(0 \%)$. Hal tersebut disebabkan karena pendidikan wanita usia subur yang rendah memahami konsep penggunaan alat kontrasepsi implant sehingga mempengaruhi pola pikir wanita usia subur dalam memahami penggunaan alat kontrasepsi implant dan tidak mengaplikasikannya kedalam kehidupannya.

Hasil penelitian pendidikan dengan perspektif Islam dan kesehatan mengenai penggunaan implant dengan mayoritas pendidikan rendah tidak menggunakan sebanyak 21 orang $(50,0)$ pendidikan tinggi tidak menggunakan KB implant sebanyak 6 orang $(14,2 \%)$. Dengan rendahnya pemakaian alat kontrasepsi yang terjadi pada pendidikan rendah dapat diketahui bahwa pendidikan rendah akan mempengaruhi pengetahuan waanita usia subur dan penggunaan terhadap alat kontrasepsi implant. Pendidikan adalah proses pengubahan sikap dan tangkah laku seseorang atau kelompok orang dalam usaha mendewasakan manusia melalui upaya pengajaran dan pelatihan, proses, perbuatan dan tata cara mendidik.

Secara Secara kualitatif diketahui bahwa informan 1 memiliki pendidikan SMP dan informan 1 memiliki pendidikan SMA. Dari kedua informan tersebut, dapat dilihat bahwa informan 1 berada pada usia pendidikan rendah sedangkan informan 2 berada pada pendidikan menenggah.

Menurut peneliti pendidikan seseorang sangat erat kaitangnnya dengan pengetahuannya semakin tinggi pendidikan seseorang maka makin tinggi tingkat pengetahuannya. Semakin tinggi tingkat pendidikan maka cara pandang orang tersebut terhadap segala sesuatu kehidupan masyarakat akan lebih luas. Semakin dewasa seseorang maka sikapnya terhadap sesuatu yang dianggapnya bermanfaat akan lebih rasional. Tingkat pendidikan seseorang menentukan seberapa besar pengetahuan yang dimilikinya. Wanita usia subur yang berpendidikan tinggi memiliki pemahaman yang lebih mengenai manfaat dari pemakaian alat kontrasepsi implant. Sehingga semakin tinggi pendidikan seseorang semakain semakin tinggi minatnya dalam pemakaian alat kontrasepsi implant. 
Hal ini sejalan dengan teori Lawrence Green menyatakan pendidikan merupakan faktor predisposisi yang cukup penting dalam mempengaruhi perilaku seseorang. Pendidikan seseorang sangat berpengaruh terhadap perilaku individu dalam mengambil setiap keputusan dan sikapnya yang selalu berpedoman pada apa yang mereka dapatkan melalui proses belajar dan pengalaman yang diterimanya.

Penelitian yang dilakukan kepada responden dalam di Klinik BPM Keluarga Sehat Kecamatan Darul Hasanah Kabupaten Aceh Tenggara Provinsi Aceh didapatkan bahwa mayoritas pengetahuan wanita usia subur dari 42 responden didapatkan penelitian didapatkan pendidikan rendah tidak menggunakan sebanyak 21 orang $(50,0 \%)$ sedangkan minoritas pendidikan rendah menggunakan alat kontrasepsi implant sebanyak 0 orang $(0 \%)$. Hal tersebut disebabkan karena pendidikan wanita usia subur yang rendah memahami konsep penggunaan alat kontrasepsi implant sehingga mempengaruhi pola pikir wanita usia subur dalam memahami penggunaan alat kontrasepsi implant dan tidak mengaplikasikannya kedalam kehidupannya.

Sementara dari hasil penelitian didapatkan Pendidikan tinggi tidak menggunakan sebanyak 6 orang $(14,2 \%)$ sedangkan minoritas pendidikan tinggi menggunakan alat kontrasepsi implant sebanyak 2 orang $(4,8 \%)$. Hal menunjukkan bahwa pendidikan wanita usia subur menjamin wanita usia subur menggunakan alat kontrasepsi implant. Semakin rendah pendidikan wanita usia subur maka semakin kurang minat wanita usia subur menggunakan alat kontrasepsi implant. Berdasarkan data tersebut dapat dievaluasi bahwa adanya pemahaman dari sisi Agama dengan doktrin tertentu sehingga wanita usia subur tidak ingin menggunakan alat kontrasepsi implant tentang alat kontrasepsi implant yang di masukkan ke dalam tubuh. Salah satu alasan terjadinya kondisi tersebut karena kurangnya pengetahuan wanita usia subur tentang manfaat alat kontrasepsi implant.

Tingkat pendidikan seseorang mengenai informasi baik atau buruk yang didapatkan dipengaruhi oleh pendidikan, pengaruh orang terdekat atau yang berpengaruh ditempat wanita usia subur berdomisili, kepercayaan yang dianut dan pengalaman. Hasil jawaban responden bila dihubungkan dengan kondisi masalah penggunaan alat kontrasepsi implant dikalangan wanita usia subur menunjukkan bahwa konsistensi dari petugas kesehatan masih kurang dalam menyampaikan informasi yang tepat kepada masyarakat. Hal ini dikaitkan dengan bagaimana pola sosial budaya atau kepercayaan masyarakat mengenai penggunaan alat kontrasepsi implant yang masih rendah. Untuk itu perlu adanya kerjasama antara tokoh Agama yang lebih dipercaya dengan petugas kesehatan itu sendiri. Masyarakat Aceh umumnya lebih percaya 
dengan agama, sehingga mereka membaca beberapa ayat tanpa dikaji lebih dalam makna yang tersirat.

Di dalam Al-qur'an, Allah telah berfirman: "Dialah yang mengutus kepada kaum yang buta seorang Rasul di antar mereka, yang membaca ayat-ayat-Nya kepada mereka, mensucikan mereka dan Hikmah (As Sunnah). Dan sesungguhnya mereka sebelumnya benarbenar dalam kesesatan yang nyata”. (QS surat Al-jumuah ayat:2). Pengertian ayat tersebut adalah: Allah-lah yang mengutuskan kepada orang-orang Arab yang tidak bisa membaca, tidak memiliki kitab dan tidak akan ke Rasulan kepada mereka, seorang Rasul dari mereka kepada seluruh manusia, yang membaca Al-Quran kepada mereka, menyucikan mereka dari akidahakidah rusak dan akhlak-akhlak buruk, megajari mereka Al-Quran dan Sunnah. sesungguhnya mereka sebelum di utus Rasulullah berada di dalam penyimpangan yang nyata dari jalan kebenaran. Allah juga mengutus Rasul tersebut kepada kaum yang lain yang belum datang dan yang akan datang dari kalangan orang-orang Arab dan lainnya. Hanya Allah semata yang maha perkasa, yang berkuasa atas segala sesuatu lagi bijaksana dalam dalam perkataan dan perbuatan.

Ayat tersebut mengajarkan kepada kita tentang pentingnya ilmu pendidikan agar kita tidak bodoh dan bisa membedakan mana yang baik dan buruk untuk dilakukan. Dengan adanya pendidikan maka seseorang bisa membedakan perilaku yang baik dan perilaku yang buruk, hal yang membayakan diri sendiri atau hal yang menguntungkan diri sendiri. Karena pendidikan yang tinggi akan meningkatkan pengetahuan seseorang dalam pengambilan sikap dan keputusan. Demikian juga dengan penggunaan kontrasepsi implant Seseorang yang sudah mengetahui tentang manfaat penggunaan kontrasepsi implant pasti akan mengikuti penggunaan KB implant.

Hubungan Paritas dengan Perspektif Islam dan Kesehatan Tentang penggunaan alat kontrasepsi implant di Klinik BPM Keluarga Sehat Kecamatan Darul Hasanah Kabupaten Aceh Tenggara

Berdasarkan table 2 hasil penelitian paritas dengan perspektif Islam dan kesehatan mengenai penggunaan implant dengan paritas primipara berjumlah 3 orang $(7,30)$, multipara tidak menggunakan sebanyak 31 orang $(31,4 \%)$ sedangkan Paritas multipara menggunakan alat kontrasepsi implant sebanyak 2 orang $(2,6 \%)$ dan tidak menggunakan sebanyak 6 orang $(15,0 \%)$. Paritas primipara dan grandemultipara tidak ada yang menggunakan alat kontrasepsi implant. Sedangkan multipara dengan hanya 2 orang yang memakai alat kontrasepsi implant.

Paritas adalah jumlah persalinan yang dialami oleh ibu baik lahir hidup maupun lahir mati, tingkat paritas telah menarik banyak perhatian para peneliti dalam hubungan kesehatan 
si ibu maupun si anak. Dikatakan bahwa terdapat kecenderungan kesehatan ibu yang paritas rendah lebih baik dari yang paritas tinggi, terdapat asosiasi antara tingkat paritas dan penyakitpenyakit tertentu.

Penelitian ini tidak sejalan dengan Penelitian Armelia dengan judul analisis tentang KB menurut Agama Islam terhadap pemakaian alat kontrasepsi di Puskemas Sigala-gala Kecamatan Topeng Kabupaten Lamongan Tahun 2015 diperoleh hasil bahwa ada hubungan pengetahuan ( $\mathrm{p}$-value $=0,004<\alpha=0,05$ ). Dengan demikian dapat disimpulkan bahwa ada hubungan yang signifikan antara paritas tentang KB menurut Agama Islam terhadap pemakaian KB dan pengetahuan ibu tentang hukum Islam dengan pemakaian alat kontrasepsi di Puskemas Sigala-gala Kecamatan Topeng Kabupaten Lamongan (Amirul Amelia 2016).

Hal ini tidak sesuai dengan teori yang mengatakan bahwa paritas seseorang wanita dapat mempengaruhi cocok tidaknya suatu metode kontrasepsi secara medis atau dapat mempengaruhi dalam memilih alat kontrasepsi yang digunakan. Secara umum, wanita nulipara dianjurkan untuk menggunakan kotrasepsi selain Implant, seperti yang hormonal. Implant tidak dianjurkan karena pemasangan yang sulit, angka ekspulsi yang lebih tinggi daripada wanita yang pernah melahirkan dan juga dapat mengganggu kesuburan di masa depan.

\section{Hubungan Jarak Pelayanan Kesehatan dengan Perspektif Islam dan Kesehatan Tentang Penggunaan Alat Kontrasepsi Implant di Klinik BPM Keluarga Sehat Kecamatan Darul Hasanah Kabupaten Aceh Tenggara}

Berdasarkan table 2 hasil penelitian penggunaan alat kontrasepsi implant dengan jarak pelayanan kesehatan dekat tidak menggunakan alat kontrasepsi implant sebanyak 26 orang $(62,0 \%)$ sedangkan menggunakan alat kontrasepsi implant sebanyak 1 orang $(2,4 \%)$ dan jarak jauh tidak menggunakan KB implant sebanyak 14 orang $(33,2 \%)$ sedangkan jarak jauh menggunakan alat kontrasepsi implant sebanyak 1 orang $(2,4 \%)$. Jarak pelayayan kesehatan yang jauh atau dekat tidak akan meningkatkan minat wanita usia subur dalam penggunaan alat kontrasepsi implant karena walau memiliki jarak yang dekat dengan fasilitas kesehatan wanita usia subur tidak memiliki minat dengan penggunaan KB implant karena kurangnya dukungan dari suami dan pengetahuan wanita usia subur yang rendah dengan penggunaan KB implant.

Semakin jauh jarak dan sulit akses menuju fasilitas kesehatan dari tempat wanita usia subur akan menurunkan motivasi wanita usia subur untuk melakukan kunjungan dalam pemakaian alat kontrasepsi implant. Jauhnya jarak akan membuat wanita usia subur berfikir dua kali untuk melakukan kunjungan dalam pemakaian alat kontrasepsi karena akan memakan banyak tenaga dan waktu setiap melakukan kunjungan. Wanita usia subur yang tidak menggunakan transportasi dan hanya berjalan kaki menuju ke tempat pelayanan kesehatan 
mayoritas memiliki angka kunjungan kefasilitas kesehatan lebih sering dalam konsultasi tentang pemakaian alat kontresepsi yang ingin digunakan. Jarak pelayanan kesehatan dari lokasi rumah wanita usia subur dikatakan jauh apabila memiliki jarak $>5 \mathrm{~km}$ dan jarak rumah wanita usia subur dengan fasilitas kesehatan dikatakan dekat apabila $<5 \mathrm{~km}$ (Nasution Pratiwi, 2015).

Hasil penelitian yang dilakukan oleh peneliti maka di dapatkan jarak pelayanan kesehatan dekat berjumlah 27 orang $(64,3 \%)$, Mayoritas jarak dekat tidak menggunakan alat kontrasepsi implant sebanyak 26 orang $(62,0 \%)$ sedangkan minoritas jarak dekat menggunakan alat kontrasepsi implant sebanyak 1 orang $(2,4 \%)$. Dari hasil penelitian tersebut menunjukkan bahwa jarak dekat antara pelayanan kesehatan dengan rumah wanita tidak akan mempengaruhi minat wanita usia subur dalam memakai implant.

\section{Hubungan Pengetahuan dengan Perspektif Islam dan Kesehatan Tentang penggunaan alat kontrasepsi implant di Klinik BPM Keluarga Sehat Kecamatan Darul Hasanah Kabupaten Aceh Tenggara}

Berdasarkan table 2 hasil penelitian pengetahuan penggunaan implant dengan jumlah pengetahuan kurang tidak menggunakan sebanyak 31 orang (73,8\%), Pengetahuan cukup sebanyak 8 orang $(19,0 \%)$ dan pengetahuan baik berjumlah 3 Orang $(7,1 \%)$, Pengetahuan baik tidak menggunakan sebanyak 3 orang $(7,1 \%)$ sedangkan menggunakan alat kontrasepsi implant sebanyak 1 orang $(2,4 \%)$. Hasil penelitian tersebut terlihat bahwa wanita usia subur yang pendidikannya tinggi menggunakan alat kontrasepsi implant dimana wanita usia subur memiliki pengetahuan yang cukup sehingga memiliki pandangan positif tentang penggunaan kontrasepsi implant.

Penelitian yang dilakukan kepada responden dalam di Klinik BPM Keluarga Sehat Kecamatan Darul Hasanah Kabupaten Aceh Tenggara Provinsi Aceh didapatkan bahwa mayoritas pengetahuan wanita usia subur dari 42 responden didapatkan mayoritas pengetahuan wanita usia subur kurang sebanyak 31 orang $(37,8 \%)$ tidak menggunakan alat kontrasepsi implant sebanyak 31 orang $(37,8 \%)$. Hal tersebut disebabkan karena pengetahuan wanita usia subur yang rendah memahami konsep penggunaan alat kontrasepsi implant sehingga mempengaruhi pola pikir wanita usia subur dalam memahami penggunaan alat kontrasepsi implant dan tidak mengaplikasikannya kedalam kehidupannya.

Sementara dari hasil penelitian didapatkan pengetahuan baik dari 3 orang $(7,1 \%)$ menggunakan alat kontrasepsi implant sebanyak 1 orang $(2,4 \%)$. Hal menunjukkan bahwa pengetahuan wanita usia subur menjamin wanita usia subur menggunakan alat kontrasepsi implant. Semakin rendah pengetahuan wanita usia subur maka semakin kurang minat wanita 
usia subur menggunakan alat kontrasepsi implant. Berdasarkan data tersebut dapat dievaluasi bahwa adanya pemahaman dari sisi Agama dengan doktrin tertentu sehingga wanita usia subur tidak ingin menggunakan alat kontrasepsi implant tentang alat kontrasepsi implant yang di masukkan ke dalam tubuh. Salah satu alasan terjadinya kondisi tersebut karena kurangnya pengetahuan wanita usia subur tentang manfaat alat kontrasepsi implant.

Di dalam Al-qur'an, Allah telah berfirman," bacalah dengan (menyebut) nama Tuhanmu yang menciptakan. Dia telah menciptakan manusia dari segumpal darah. Bacalah, dan Tuhanmu Yang Maha Pemurah, yang mengajar (manusia) dengan perantaran kalam. Dia mengajar kepada manusia apa yang tidak diketahuinya.”(Q.S. Al-alaq: 1-5). Pengertian dari ayat tersebut adalah mengajarkan kepada manusia bahwa Allah SWT memuliakan/menjunjung tinggi martabat manusia melalui baca yang berarti dengan proses belajar mengajar itu manusia dapat menguasai ilmu-ilmu pengetahuan, sehingga manusia dapat mengetahui rahasia alam semesta yang bermanfaat bagi kesejahteraan hidupnya. Surat Al-alaq juga mengandung perintah membaca yang berarti berpikir secara teratur atau sistematis dalam mempelajari firman dan ciptaan-Nya, berpikir dengan mengkorelasikan antara ayat qauliah dan kauniah,sehinga manusia menemukan konsep-konsep sains dan ilmu pengetahuan.

\section{Hubungan Dukungan Suami Dengan Perspektif Islam dan Kesehatan Tentang} Penggunaan Alat Kontrasepsi Implant di Klinik BPM Keluarga Sehat Kecamatan Darul

\section{Hasanah Kabupaten Aceh Tenggara}

Berdasarkan table 2 hasil penelitian mengenai penggunaan alat kontrasepsi implant suami mendukung serta tidak menggunakan alat kontrasepsi implant sebanyak 3 orang $(7,1 \%)$ sedangkan suami mendukung menggunakan implant 2 orang $(4,8 \%)$. Dan suami suami tidak mendukung tidak menggunakan implant sebanyak 37 orang $(88,1 \%)$. Peran suami dalam penggunaan alat kontrasepsi implant sangat mendukung wus dalam pemakaian implant karena dengan adanya dorongan dan motivasi dari seorang suami kepada istrinya akan menghilangkan sikap negatif seorang istri tentang suatu keadaan yang dia anggap menakutkan dalam penggunaan KB implant. Dukungan suami memiliki peran utama dalam peningkatan minat wanita usia subur dalam penggunaan alat kontrasepsi implant.

Hasil penelitian menunjukkan bahwa mayoritas suami tidak mendukung penggunaan KB implant sebanyak 37 orang $(88,1 \%)$, suami tidak mendukung dan tidak menggunakan implant sebanyak 37 orang $(88,1 \%)$ dan menggunaaan KB impant sebanyak 0 orang $(0 \%)$. Data tersebut menunjukkan dukungan suami sangat penting terkait dengan penggunaan alat kontrasepsi implant pada wanita usia subur. Dukungan suami terkait bagaimana cara suami mengantarkan wanita usia subur untuk memilih dan menggunakan alat kontrasepsi implant 
serta memberi dukungan penuh berupa menemani wanita usia subur ke pusat pelayanan kesehatan dalam pemakian alat kontrasepsi implant. Peran domestik inilah yang biasanya dijadikan sebagai bahan agar suami memberikan informasi terkait manfaat penggunaan alat kontrasepsi implant dan menginggatkan kepada istri kapan pencabutan alat kontrasepsi implant tersebut. Dari segi agama suami mencari tahu tentang kandungan alat kontrasepsi tersebut kepada para ulama agar tidak ada keraguan istri dalam pemakian alat kontrasepsi implant.

Dalam Al-qur'an dan hadist juga dijelaskan dalam dari Abu Hurairah dari Nabi Shallallahu Alaihi Wassallam, dia berkata, "Ya Allah sungguh aku kecam orang yang mengabaikan hak dua orang yang lemah: yaitu anak yatim dan seorang istri”. (HR. Ahmad dalam “Al Musnad”, 15/416, cetakan Mussasah ar Risalah). Penelitian Salviana dengan judul analisis yang mempengaruhi rendahnya minat ibu untuk menggunakan metode implant pada akseptor KB di Puskesmas Kasi-Kasi Makasar diperoleh hasil bahwa ada hubungan yang bermakna antara Dukungan suami (p-value 0,002 $<\alpha=0,05$ ). Dengan demikian dapat disimpulkan bahwa ada hubungan yang signifikan antara dukungan suami dengan rendahnya pemakaian metode kontrasepsi implant di Puskesmas Kassi-Kassi Makassar (Salviana, 2013). Hubungan Sikap Dengan Perspektif Islam dan Kesehatan Tentang Penggunaan Alat Kontrasepsi Implant di Klinik BPM Keluarga Sehat Kecamatan Darul Hasanah Kabupaten Aceh Tenggara

Berdasarkan table 2 hasil penelitian kontrasepsi implant didapatkan dari wanita usia subur tidak menggunakan alat kontrasepsi implant dengan sikap negatif terhadap alat kontrasepsi impant 36 orang $(85,7 \%)$ dan tidak menggunakan alat kontrasepsi implant dengan sikap positif sebanyak 4 orang $(9,5 \%)$ dan menggunakan alat kontrasepsi implant bersikap positif orang $(4,8 \%)$.

Ditinjau dari hasil penelitian dapat dilihat bahwa mayoritas menunjukkan bahwa sikap negatif sebanyak 36 orang $(85,7 \%)$ mengalami tidak menggunakan kontrasepsi implant sebanyak 36 orang $(85,7 \%)$ dan menggunakan kontrasepsi implant sebanyak 0 orang $(0,0 \%)$. Hal ini disebabkan karena adanya pengaruh dari intensitas sikap dalam menerima stimulus atau pengetahuan yang mendominasi didalam pikirannya yaitu aspek kesehatan dan aspek agama yang nantinya stimulus tersebut akan mempengaruhi tanggapan atau pendapat ibu mengenai stimulus tersebut dan mulai memberikan nilai positif terhadap stimulus tersebut bahkan menanggung jawab atas sikap yang ibu ambil walaupun adanya stimulus baru yaitu risiko penggunaan alat kontrasepsi implant dari sisi kesehatan yang tidak sesuai dengan keyakinan wanita usia subur selama ini. 
Sebagaimana dalam Al-qur'an Q.S Al-Jasiyah, “Kemudian kami jadikan kamu berada dalam satu syariat (peraturan) dalam urusan Agama itu. Maka ikutilah syariat itu dan janganlah kamu ikuti hawa nafsu orang-orang yang tidak mengetahui”. Ayat tersebut menegaskan bahwa sebagai umat beragama, seharusnya manusia memiliki sikap untuk mengikuti peraturan yang ditetapkan oleh Allah SWT dalam berpikir dan bertindak sesuai dengan asumsi dirinya mengenai pemahaman secara Agama.

\section{KESIMPULAN}

Kesimpulan dalam penelitian ini adalah ada hubungan pendidikan, pengetahuan, dukungan suami dan sikap pemakaian alat kontrasepsi implant dan tidak ada hubungan umur, paritas dan jarak pelayanan dengan pemakaian alat kontrasepsi implant di Klinik BPM Keluarga Sehat Kecamatan Darul Hasanah Kabupaten Aceh Tenggara Provinsi Aceh tahun 2019. Secara komprehensif wawancara langsung yang dilakukan informan wanita usia subur dan suami memberikan tanggapan yang negatif terhadap pemakaian alat kontrasepsi implant, sedangkan informan lain seperti Kepala Desa, Imam Kampung, Bidan Desa dan Petugas BKKBN memberikan reaksi yang positif dengan mengatakan bahwa penggunaan alat kontrasepsi implant boleh saja dilakukan pemakaiannya pada wanita usia subur jika dilihat dari segi Agama dan kesehatan.

\section{SARAN}

1. Bagi Wanita Usia Subur

a. Wanita usia subur yang sudah mengetahui dan memahami pentingnya manfaat pemakian alat kontrasepsi dan hukum pemakaiannya implant secara Agama Islam hendaknya memakai alat kontrasepsi implant untuk menjarangkan kehamilannya.

2. Bagi Puskesmas

a. Disarankan kepada tenaga kesehatan di Puskesmas khususnya Bidan untuk meningkatkan konseling dan penyuluhan yang lebih intensif mengenai manfaat pemakaian alat kontrasepsi implant sehingga masyarakat tertarik menggunakan alat kontrasepsi sebagai pencegahan dan penjarangan kehamilan.

b. Melakukan upaya penyuluhan secara berkala tentang hukum pemakaian alat kontrasepsi implant dari segi kesehatan dan Agama Islam dengan melibatkan kerjasama para tokoh masyarakat seperti RW, RT dan para kader di setiap desa agartidak terjadi anggapan yang salah dimasyarakat tentang penggunaan alat kontrasepsi implant.

3. Bagi peneliti selanjutnya 
a. Peneliti lain dapat menjadikan data pada penelitian ini sebagai data dasar bagi penelitiannya. Peneliti lain disarankan menambah variabel faktor predisposisi, faktor pemungkin, dan faktor penguat yang lain terhadap penggunaan alat kontrasepsi implant agar masyarakat mengetahui tentang manfaat pemakaian alat kontrasepsi implant.

b. Peneliti lain disarankan melakukan penelitian di tempat lain dengan pandangan berbeda dari Agama lain tentang penggunaan alat kontrasepsi implant dengan metode atau desain yang berbeda, dan jumlah responden yang lebih besar.

4. Bagi Masyarakat

a. Disarankan pada masyarakat agar ikut aktif hadir atau berperan serta apabila ada kegiatan penyuluhan yang diselenggarakan oleh tenaga kesehatan dari Puskesmas khususnya penyuluhan tentang penggunaan alat kontrasepsi implant.

b. Untuk suami atau keluarga agar memberikan dukungan terhadap wanita usia subur yang dengan cara mengantar, mengingatkan wanita usia subur untuk mendapatkan pelayanan pemakaian alat kontrasepsi terutama alat kontrasepsi implant.

\section{DAFTAR PUSTAKA}

Hartono. Keluarga Berencana dan Kontrasepsi. Jakarta: Pusat Sinar Harapan; 2016.

Kementerian Kesehatan RI pusat data dan informasi. Kemenkes RI. Januari 2018. Jakarta 2018. Available from: depkes.go.id.

Taharudin. Profit Kesehatan Aceh tahun 2017. Aceh Dinkes Provinsi Aceh. Aceh; 2015. Available from: acehprov.co.id.

Dinkes Kabupaten Aceh Tenggara. Dinkes Agara; 2018. Available from: DinkesAgara.co.id.

Yakup. KB dan Penggunaan Kontrasepsi Di Tinjau dari Sudut Pandang Islam. Contracept Fast. 2015.

Faisal Ali. Identitas Aceh Dalam Perspektif Syariat dan Adat. Banda Aceh: Yayasan PeNa; 2013.

Syam H. Analisis Pendukung dan Penghambat Pasangan Usia Subur Dalam Pemilihan Alat Kontrasepsi Implant di Desa Kaba Kabupaten Pangkap Tahun 2015;4 no 4;332. Available from: Kebidanan Vakasional. 2017.

Amalia Amirul. Analisis Tentang KB Menurut Agama Islam Terhadap Pemakaian Alat Kontrasepsi Di BPS Anik Astuti Dusun Jatirejo Desa Topeng Kecamatan Tikung Kabupaten Lamongan Tahun 2016. Available from: hhtp://jurnal.fkm.unand.ac.id/indeks.jkma/. 
Syafneli. Analisis Faktor-Faktor Yang Berhubungan Dengan Rendahnya Minat Ibu Dalam Menggunakan KB Implant Tambusai Kabupaten Rokan Hulu Tahun 2014. Available from:https://.Maternal Neonatal.ac.id.

Nasution Pratiwi. Analisis Faktor Untuk Mengetahui Hambatan Dalam Penggunaan Alat Kontrasepsi Implant Di Desa Suka Maju Kecamatan Sunggal Kabupaten Deli Serdang Tahun 2015. Available from: digilib.usisayogya.ac.id.

Salviana. Analisis Yang Mempengaruhi Rendahnya Minat Ibu Untuk Menggunakan Metode Implant Pada Akseptor KB di Puskesmas Kasi-Kasi Tahun 2013. Available from: Maternal Neonatal. 2013.

Misrina. Analisis Yang Memengaruhi Penggunaan Metode Kontrasepsi Jangka Panjang (MKJP) di Desa Teupan Raya Peusangan Krueng Kabupaten Bireuen. Available from: J Healthcare Med. 2018.

Siswosudarmo. Perkembangan Tehnologi Kontrasepsi.Yogyakarta: Medika Fakultas Kedoteran UGM. 2012.

Aziz Alimul. Buku Ajar Pelayanan Kesehatan Reproduksi dan Keluarga Berencana. Yogyakarta: Pustaka Rihama; 2010.

Dyah Noviawati Setya. Asuhan kebidanan dan Pelayanan Keluarga Berencana. Jakarta; 2015.

Diah noviawati setyaningrum. Panduan Lengkap Pelayanan Keluarga Berencana Terkini. Yogyakarta. Nuha Medika; 2013.

Susiltiawati. Pelayanan Keluarga Berencana. Jakarta; Trans Info Media. 2014.

Sulystia Ningsih. Metode Penelitian Kebidanan Kualitatif dan Kuantitatif dan Campuran. Pustaka Baca: 2011. 